\title{
PENGEMBANGAN SISTEM PEER-EVALUATION PADA EDUFI LEARNING MANAGEMENT SYSTEM BERBASIS RASPBERRY PI
}

\author{
Haris $^{1}$, Muhaimin Hasanudin ${ }^{2}$, Wahyu Hidayat ${ }^{3}$ \\ ${ }^{1}$ AMIK Raharja ${ }^{2,3}$ STMIK Raharja \\ ${ }^{1,2,3}$ Program Studi Teknik Informatika, Perguruan Tinggi Raharja, \\ J1. Jenderal Sudirman No.40 Modern Cikokol Tangerang, 15117, Indonesia \\ E-mail: ${ }^{1}$ haris@raharja.info, ${ }^{2}$ muhaimin@raharja.info, ${ }^{3}$ wahyu@raharja.info
}

\begin{abstract}
Abstrak
Pada era industri 4.0 dibutuhkan lulusan perguruan tinggi yang dapat bekerja dengan kemampuan berpikir kritis dan terbiasa berkolaborasi dalam kelompok kerja. Sehingga dibutuhkan sistem pembelajaran yang berpusat pada mahasiswa. Penerapan peer-evaluation pada model pembelajaran Collaborative Learning dapat meningkatkan hasil belajar mahasiswa dan membentuk lulusan yang dapat berpikir kritis. Implementasi sistem Learning Management System pada umumnya menggunakan koneksi internet dalam proses pembelajaran, namun pada daerah tertentu di Indonesia masih ada lingkungan kampus yang belum bagus koneksi internetnya. Oleh karena itu dibutuhkan sistem Learning Management System yang dapat diterapkan pada mini komputer yang dapat diimplementasikan sebagai server sekaligus wifi hotspot. Edufi LMS berbasis Raspberry Pi dapat diimplementasikan untuk pembelajaran dengan sistem peer-evaluation pada model Collaborative Learning.
\end{abstract}

Kata kunci-Edufi Learning Management System, Peer-Evaluation, Collaborative Learning

\begin{abstract}
In the industrial era 4.0, higher education graduates are needed who can work with critical thinking skills and are accustomed to collaborating in work groups. So it takes a studentcentered learning system. The application of peer evaluation on Collaborative Learning learning models can improve student learning outcomes and form graduates who can think critically. The implementation of the Learning Management System generally uses an internet connection in the learning process, but in certain regions in Indonesia there is still a campus environment that has not good internet connection. Therefore, a Learning Management System is needed that can be applied to mini-computers that can be implemented as servers as well as wifi hotspots. Edufi Raspberry Pi-based LMS can be implemented for learning with a peerevaluation system in the Collaborative Learning model.
\end{abstract}

Keywords-Edufi Learning Management System, Peer-Evaluation, Collaborative Learning

\section{PENDAHULUAN}

Sistem pembelajaran pada mahasiswa mempunyai peranan penting dalam sistem perkuliahan yang ada pada suatu perguruan tinggi. Sistem pembelajaran tersebut mewajibkan mahasiswa untuk memenuhi beberapa persyaratan mulai dari absensi, tugas mandiri, ujian tengah semester dan ujian akhir semester. 
Computatio: Journal of Computer Science and Information Systems, volume 2, no 2, Oktober 2018

Tugas mandiri adalah tugas yang diberikan oleh dosen kepada mahasiswa berupa tugastugas yang diberikan yang terkait dengan mata kuliah. Dengan adanya tugas mandiri, mahasiswa bisa belajar dengan aktif. Tugas mandiri tersebut bisa berbentuk diskusi antara kelompok, presentasi makalah, latihan-latihan soal dan lain sebagainya. Dengan adanya tugas mandiri, mahasiswa jadi lebih mengerti tentang matakuliah dan penjabarannya.

Berdasarkan Permendikbud No. 49 tahun 2014 tentang Standar Nasional Pendidikan Tinggi, semua Program Studi dituntut untuk menghasilkan lulusan yang memenuhi standar minimal dalam kualifikasi KKNI (Kerangka Kualifikasi Nasional Indonesia). Kurikulum pembelajaran yang mengacu pada KKNI sudah tidak menggunakan pendekatan Teacher Centered Learning (TCL) yang menerapkan pembelajaran berpusat pada Dosen. Pendekatan yang digunakan dalam KKNI adalah Student Centered Learning (SCL) yang menerapkan pembelajaran dengan mengutamakan pengembangan kreativitas, kapasitas, kepribadian, dan kebutuhan mahasiswa, serta mengembangkan kemandirian dalam mencari dan menemukan pengetahuan.

Dalam penerapan SCL dapat menggunakan beberapa jenis metode pembelajaran seperti Small Group Discussion, Role-Play \& Simulation, Case Study, Discovery Learning (DL) dan Self-Directed Learning (SDL), Cooperative Learning (CL), Collaborative Learning (CbL), Project Based Learning (PjBL) dan Problem Based Learning and Inquiry (PBL). Dalam penelitian ini, peneliti akan menggunakan metode Collaborative Learning. Yang dimaksud dengan Collaborative Learning adalah metode belajar yang menitikberatkan pada kerjasama antar mahasiswa yang didasarkan pada kesepakatan yang dibuat sendiri oleh anggota kelompok. Masalah, tugas dan kasus berasal dari dosen dan bersifat open-ended, tetapi pembentukan kelompok didasarkan pada minat, prosedur kerja kelompok, penentuan waktu dan tempatdiskusi/kerja kelompok, sampai dengan bagaimana hasil diskusi/kerja kelompok ini dinilai oleh dosen, semuanya ditentukan melalui konsensus bersama antar anggota kelompok.

Proses penilaian dalam pembelajaran SCL dilakukan selama proses pembelajaran berlangsung, yakni dengan memeriksa perkembangan hasil capaian pembelajaran yang diraih mahasiswa. Atas dasar ini, assessment atau penilaian tidak sekedar memvonis dan mencari-cari kesalahan, melainkan lebih pada memeriksa, mengkaji, memberi arahan dan masukan kepada mahasiswa agar mampu memenuhi tuntutan capaian pembelajaran yang ditetapkan.

Dengan memanfaatkan e-learning sebagai media pembelajaran, akan membuat materi pelajaran dan pembelajaran yang disampaikan menjadi lebih interaktif, karena materinya dapat berupa teks, grafik, animasi, simulasi, audio dan video [1]. Dalam prakteknya e-learning bersifat jaringan internet yang membuatnya dapat memperbaiki materi pelajaran secara cepat, menyimpan atau memunculkan kembali, mendistribusikan, dan sharing pembelajaran dan informasi. Disamping banyaknya manfaat dari penggunaan internet sebagai sarana pembelajaran dengan e-learning, terdapat juga masalah yang muncul dalam proses pembelajaran bagi peserta didik yang mengakses e-learning melalui koneksi internet. Pada umumnya peserta didik belum mampu memilah aktivitas internet yang bermanfaat dan cenderung mudah terpengaruh oleh lingkungan sosial tanpa mempertimbangkan terlebih dahulu efek positif atau negatif yang akan diterima saat melakukan aktivitas internet tertentu [2].

Selain dampak negatif dari sisi konten, penerapan e-learning dengan jaringan internet membuat pihak institusi harus menyediakan koneksi internet sebagai jalur komunikasi antara server e-learning dengan peserta didik. Demikian juga bagi peserta didik dalam e-learning memerlukan paket data internet agar bisa mengakses website e-learning untuk melakukan download bahan ajar, upload file tugas atau quiz, membaca dan merespon forum online, maupun melihat video presentasi pelajaran atau tugas. Sehingga akan membuat pengeluaran biaya yang cukup besar bagi institusi pendidikan maupun para peserta didik dalam kegiatan belajar mengajar dengan media koneksi internet. Pada umumnya institusi pendidikan menggunakan server dengan kapasitas yang besar dengan harga cukup mahal dalam pengadaan 
Haris, et al., Pengembangan Sistem Peer-Evaluation Pada Edufi Learning Management System

server e-learning. Dengan penggunaan komputer Server e-learning yang beroperasi selama 24 jam dalam sehari, dan 7 hari dalam seminggu, akan memerlukan ruangan dengan berpendingin AC, agar server tidak overheat. Sehingga akan menimbulkan biaya listrik yang cukup mahal untuk pengoperasian komputer server dan AC dalam penyelenggaraan e-learning.

Oleh karena itu dibutuhkan rancang bangun sistem Learning Management System yang dapat beroperasi dengan komputer yang hemat daya listrik, beroperasi tanpa harus menggunakan ruangan berpendingin AC, tanpa menggunakan jaringan internet serta aman dari content negatif dan virus komputer. Sejak tahun 2006, sudah dikembangkan komputer berukuran kecil dan relatif murah serta dapat digunakan untuk aplikasi web. Raspberry Pi dapat menjadi mikrokontroller sekaligus sebagai komputer yang mampu mengaplikasikan program berbasis grafis. Dalam implementasi pembelajaran dengan e-learning dapat menggunakan Raspberry Pi sebagai Web Server [3][4] dan beroperasi di jaringan Local Area Network (LAN) dengan Wifi Hotspot yang tidak perlu terhubung ke jaringan internet. Bagi para pendidik dan peserta didik dapat terhubung ke Web Server dengan koneksi Wifi yang akan memberikan IP dinamis (DHCP) pada perangkat yang akan digunakan oleh pengguna e-learning. Raspberry Pi berukuran kecil sebesar kartu ATM, sehingga dapat diletakkan pada box kecil yang diletakkan menempel di dinding bagian atas. Walaupun dengan konfigurasi yang diusulkan ini hanya menggunakan LAN tanpa jaringan internet, namun semua manfaat dari pembelajaran e-learning dapat diimplementasikan.

\section{METODE PENELITIAN}

Untuk membangun Sistem Education Wifi (EduFi) akan menggunakan metode penelitian yang meliputi Metode Pengumpulan Data, Metode Pengembangan Sistem, Arsitektur Sistem EduFi, teknik pengumpulan data untuk pengembangan sistem, dan pengembangan antar muka pengguna (user interface). Pada beberapa penelitian menggunakan metode kualitatif, dapat dijelaskan pendekatan yang digunakan, proses pengumpulan dan analisis informasi, dan proses penyimpulan hasil penelitian.

\subsection{Metode Pengumpulan Data}

Tahap pertama peneliti melaksanakan kegiatan field research di AMIK Raharja Tangerang melalui pendekatan survei. Pada tahap awal ini data lapangan diperlukan dalam rangka untuk mengetahui sistem pembelajaran yang digunakan kampus saat ini, apakah masih menggunakan e-learning atau menggunakan kelas konvensional. Teknik pengumpulan data yang dipilih adalah melalui wawancara mendalam (indepth interview), Focus Group Discussion (FGD) dan studi dokumenter. Berdasarkan data tahap pertama, akan didesain dan diimplementasikan sistem EduFi serta diujicobakan di kampus.

Pada tahap kedua peneliti melaksanakan kegiatan field research di AMIK Raharja Tangerang melalui pendekatan survei. Pada tahap kedua ini data lapangan diperlukan dalam rangka untuk mengetahui penerapan e-learning yang digunakan kampus saat ini, apakah penerapane-learningmasih tersisipi content negatif atau sudah aman dari content negatif. Teknik pengumpulan data yang dipilih adalah melalui wawancara mendalam (indept interview), Focus Group Discussion (FGD) dan studi dokumenter. Berdasarkan data tahap kedua, akan didesain dan diimplementasikan sistem e-learning di jaringan komputer local kampus yang aman dari content negatif.

Pada tahap ketiga peneliti melaksanakan kegiatan field research di AMIK Raharja Tangerang melalui pendekatan survei. Pada tahap ketiga ini data lapangan diperlukan dalam rangka untuk mengetahui penerapan e-learning yang digunakan kampus saat ini, apakah masih menggunakan e-learning berbasis internet atau Local Area Network (LAN). Teknik 
Computatio: Journal of Computer Science and Information Systems, volume 2, no 2, Oktober 2018

pengumpulan data yang dipilih adalah melalui wawancara mendalam (indepth interview), Focus Group Discussion (FGD) dan studi dokumenter. Berdasarkan data tahap ketiga, akan didesain dan diimplementasikan sistem EduFi berbasis Raspbery Pi di jaringan komputer lokal kampus.

Strategi kegiatan penelitian ini akan dilakukan dengan mekanisme seperti terlihat dalam gambar 1 berupa fishbone diagram mengenai sebab-akibat penelitian:

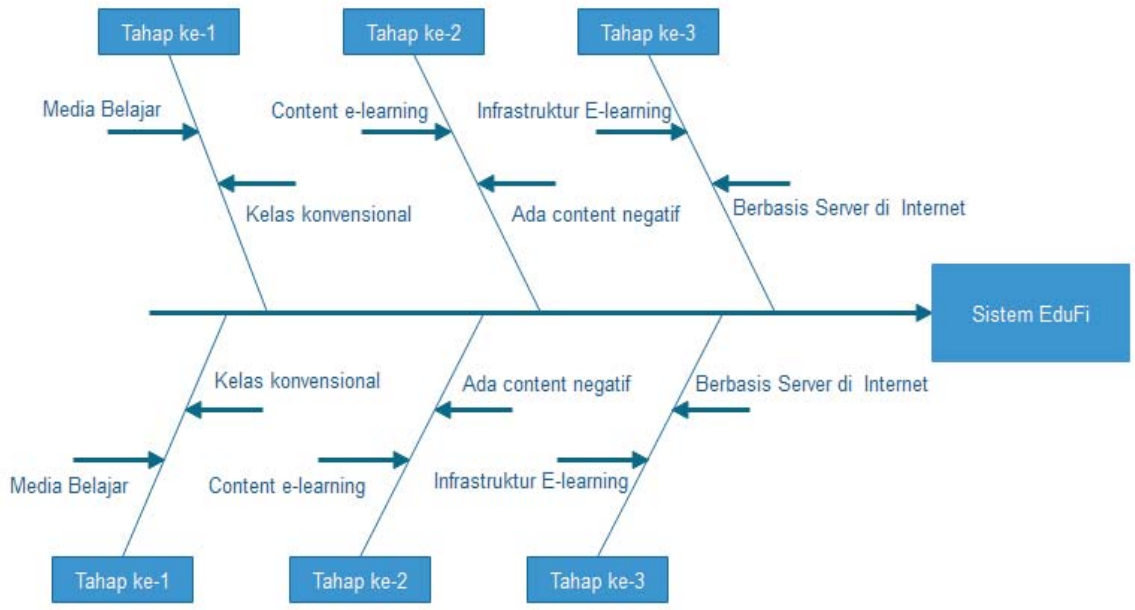

Gambar 1. Diagram Sebab-Akibat Penelitian

\subsection{Metode Pengembangan Sistem}

Metode penelitian yang digunakan adalah metode SDLC (System Development Life Cycle) jenis Waterfall yang cocok untuk menggambarkan sistem. model Waterfall atau sering disebut model sekuensial linier atau alur hidup klasik, menyediakan pendekatan alur hidup perangkat lunak secara sekuensial atau terurut dimulai dari analisis, desain, pengodean, pengujian, dan tahap pemeliharaan [5] seperti yang disajikan pada gambar 2.

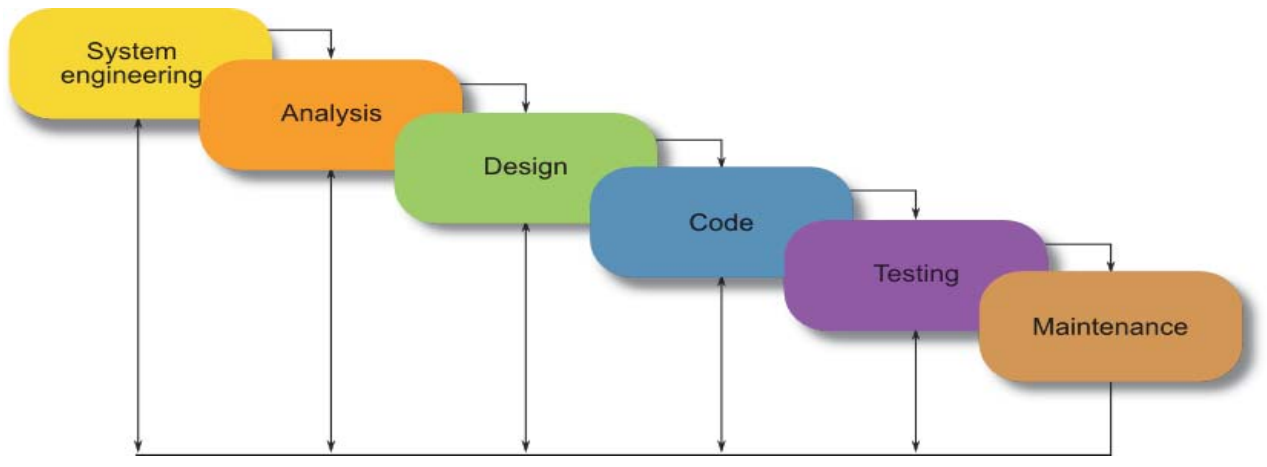

Gambar 2. Model Waterfall

\subsection{Raspberry $P i$}

Raspberry Pi adalah komputer mikro berukuran seperti kartu ATM yang dikembangkan oleh Raspberry Pi Foundation, Inggris [6]. Komputer single board ini dikembangkan dengan tujuan untuk mengajarkan dasar-dasar ilmu komputer dan pemrograman untuk siswa sekolah di seluruh dunia [7]. Meskipun mikrokontroler yang memiliki fisik seperti Arduino, dimana lebih 
dikenal untuk proyek-proyek prototyping, tidak demikian dengan Raspberry Pi yang sangat berbeda dari mikrokontroler kebanyakan, dan sebenarnya lebih seperti komputer daripada Arduino. Raspberry Pi terdiri dari banyak bagian perangkat keras yang penting dengan beberapa fungsi yang penting seperti pada gambar 3. Bagian utama dari Raspberry Pi adalah processor nya. Setiap Raspberry Pi memiliki BCM2835 Chip Broadcom yang mewujudkan suatu CPU inti Quad-core ARMv8. Chip ini memiliki clock speed $700 \mathrm{MHz}$ dan merupakan sistem 32-bit. Raspberry Pi memiliki slot kartu SD untuk kartu SD yang bertindak sebagai media penyimpanan yang semuanya termasuk sistem operasi dan file lainnya disimpan dalam kartu SD. Port HDMI digunakan sebagai audio dan video output. Sebuah HDMI ke DVI (Digital Visual Interface) converter dapat digunakan untuk mengkonversi sinyal HDMI ke DVI yang biasanya digunakan oleh monitor. Raspberry Pi membutuhkan catu tegangan 5V DC melalui micro USB. Perangkat ini juga memiliki konektor video komposit RCA untuk output video serta jack stereo 3,5 mm untuk output audio. Raspberry Pi memiliki 26 GPIO pin yang membantu untuk terhubung ke peripheral tingkat rendah dan expansion boards.

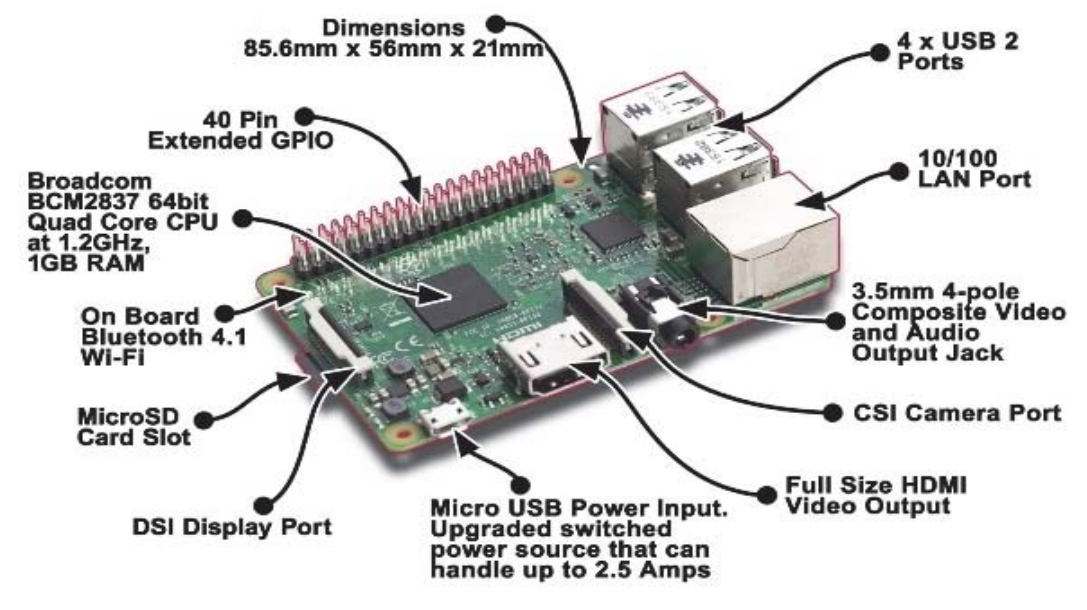

Gambar 3. Raspberry Pi 3 Model B

\subsection{Learning Management System (LMS)}

Learning Management System (LMS) adalah sebuah perangkat lunak atau software untuk keperluan administrasi, dokumentasi, pencarian materi, laporan sebuah kegiatan,pemberian materi-materi pelatihan kegiatan belajar mengajar secara online yang terhubung ke internet [8].

LMS digunakan untuk membuat materi pembelajaran online berbasiskan web dan mengelola kegiatan pembelajaran serta hasil-hasilnya. LMS ini sering disebut juga dengan platform e-learning atau learning content management system (LCMS). Intinya LMS adalah aplikasi yang mengotomasi dan memvirtualisasi proses belajar mengajar secara elektronik.

\subsection{Student Centered Learning}

Ketidakefektifan pembelajaran Teacher Centered Learning (TCL) yang satu arah, menyebabkan perubahan paradigma pembelajaran di perguruan tinggi, yakni dari satu arah menjadi multi arah atau setidaknya berpusat pada mahasiswa (Student Centered Learning). Dengan pola ini, capaian pembelajaran dapat dicapai secara terukur. Pola pembelajaran multi arah adalah pola pembelajaran yang memungkinkan mahasiswa dan dosen serta sesama mahasiswa itu sendiri dapat saling tukar informasi, saling kritik dan argumentasi. Adapun pembelajaran yang berpusat pada mahasiswa adalah pembelajaran yang mengutamakan 
Computatio: Journal of Computer Science and Information Systems, volume 2, no 2, Oktober 2018

pengembangan kreatifitas, kapasitas, kepribadian, dan kebutuhan mahasiswa, serta mengembangkan kemandirian dalam mencari dan menemukan pengetahuan. Mahasiswa harus didorong untuk gigih melakukan eksperimentasi pembelajaran sehingga mampu mencapai hasil pembelajaran yang diinginkan.

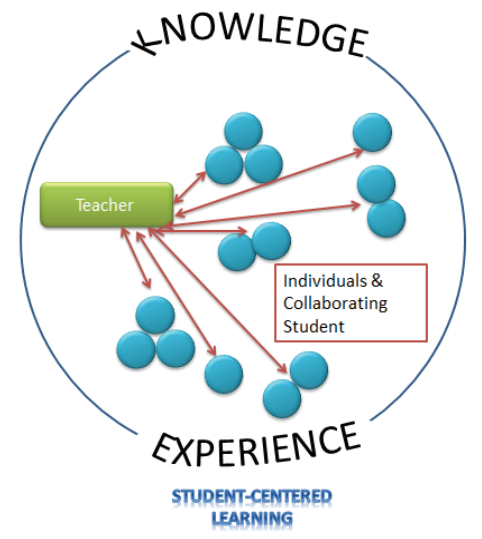

Gambar 4. Student Centered Learning (SCL)

Perubahan pembelajaran dari Teacher Centered Learning (TCL) menjadi Student Centered Learning (SCL) adalah perubahan pada level paradigma pembelajaran atau perubahan cara pandang. Paradigma pembelajaran SCL setidaknya memiliki perbedaan dalam memandang tiga komponen penting dalam pembelajaran. Pertama, pengetahuan. Dalam pembelajaran SCL, pengetahuan yang semula dipandang sebagai sesuatu yang sudah jadi dan tinggal ditransfer dari dosen ke mahasiswa, menjadi pengetahuan hasil interaksi kolaboratif dan bersifat transformatif antara dosen dan mahasiswa. Kedua, kegiatan pembelajaran. Kegiatan pembelajaran dalam SCL mengubah pola belajar yang semula hanya menerima pengetahuan (pasif-reseptif) menjadi kegiatan mencari dan mengkonstruksi pengetahuan, melalui cara-cara yang aktif dan spesifik caranya. Ketiga, dalam kegiatan pembelajaran SCL, dosen yang semula hanya menyampaikan pengetahuan atau mengajar (ceramah dan kuliah) menjadi dosen yang kini berpartisipasi aktif bersama mahasiswa mengonstruksi pengetahuan.

\subsection{Collaborative Learning}

Dalam penelitian ini, peneliti akan menggunakan metode Collaborative Learning. Yang dimaksud dengan Collaborative Learning adalah metode belajar yang menitikberatkan pada kerjasama antar mahasiswa yang didasarkan pada kesepakatan yang dibuat sendiri oleh anggota kelompok. Masalah, tugas dan kasus berasal dari dosen dan bersifat open-ended, tetapi pembentukan kelompok didasarkan pada minat, prosedur kerja kelompok, penentuan waktu dan tempat diskusi/kerja kelompok, sampai dengan bagaimana hasil diskusi/kerja kelompok ini dinilai oleh dosen, semuanya ditentukan melalui konsensus bersama antar anggota kelompok.

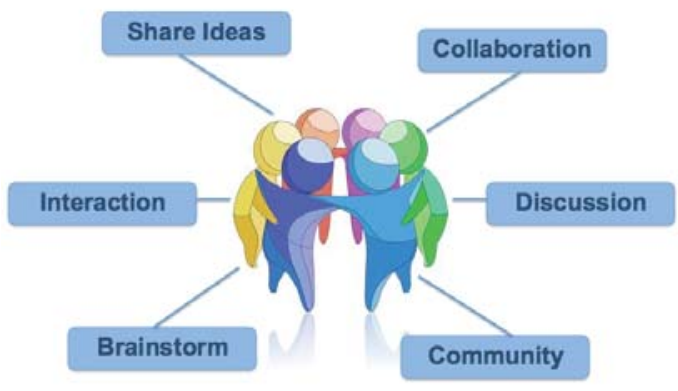

Gambar 5. Collaborative Learning 
Haris, et al., Pengembangan Sistem Peer-Evaluation Pada Edufi Learning Management System

Metode belajar CBL merupakan situasi dimana dua atau lebih mahasiswa belajar atau mencoba untuk memecahkan masalah secara bersama-sama. Tidak seperti belajar individu, orang yang terlibat dalam pembelajaran kolaboratif memanfaatkan satu sama lain sumber daya dan keterampilan (meminta satu sama lain untuk informasi, mengevaluasi ide orang lain, pemantauan pekerajaan satu sama lain, dan sebagainya). Lebih khusus, pembelajaran kolaboratif didasarkan pada filosofi bahwa pengetahuan dapat dibuat dalam populasi dimana setiap anggota aktif berinteraksi dengan berbagi pengalaman.

Pembelajaran kolaboratif sangat berakar pada pandangan Vygotsky bahwa ada sifat sosial yang melekat pada pembelajaran yang ditampilkan melalui teorinya tentang zona pengembangan proksimal. Sering kali pembelajaran kolaboratif digunakan sebagai istilah umum untuk berbagai pendekatan dalam pendidikan yang melibatkan upaya intelektual bersama oleh mahasiswa dan dosen. Dengan demikian, pembelajaran kolaboratif umumnya digambarkan ketika sekelompok mahasiswa bekerja sama untuk mencari pemahaman, makna, solusi atau menciptakan artefak atau produk pembelajaran mereka.

Pembelajaran kolaboratif terjadi ketika individu secara aktif terlibat dalam sebuah komunitas dimana pembelajaran tadi melalui upaya kolaboratif eksplisit atau implisit. Pembelajaran kolaboratif sering digambarkan sebagai semata-mata proses kognitif dimana dosen berpartisipasi sebagai fasilitator pengetahuan dan mahasiswa sebagai penerima. Namun masyarakat adat dari Amerika menggambarkan bahwa pembelajaran kolaboratif terjadi karena partisipasi individu dalam belajar terjadi pada bidang horizontal dimana mahasiswa dan dosen adalah sama. Pembelajaran kolaboratif hanya akan terjadi ketika mahasiswa dan dosen terlibat dalam diskusi, bekerja, dan kegiatan lainnya secara bersama-sama.

\subsection{Penilaian Hasil Belajar Mahasiswa}

Penilaian merupakan proses pengumpulan, pelaporan, penggunaan informasi tentang hasil belajar anak didik dengan menerapkan prinsip-prinsip penilaian, pelaksanaan berkelanjutan, bukti-bukti autentik, akurat, dan konsisten (Mulyasa, 2012: 195). Penilaian hendaknya berorientasi pada ketercapaian pembelajaran, bukan vonis terhadap kesalahan. Artinya, penilaian masih bisa berubah selama mahasiswa yang bersangkutan bersedia untuk memperbaiki proses dan hasil pembelajarannya.

Proses penilaian dalam pembelajaran SCL dilakukan selama proses pembelajaran berlangsung, yakni dengan memeriksa perkembangan hasil capaian pembelajaran yang diraih mahasiswa. Atas dasar ini, assessment atau penilaian tidak sekedar memvonis dan mencari-cari kesalahan, melainkan lebih pada memeriksa, mengkaji, memberi arahan dan masukan kepada mahasiswa agar mampu memenuhi tuntutan capian pembelajaran yang ditetapkan. Proses penilaian ini tetap menggunakan instrumen sebagai tolak ukur ketercapaian kemampuan.

\subsection{Arsitektur Sistem LMS}

Sistem LMS EduFi berbasis Raspberry Pi ini terdiri bagian Server dan bagian Client. Pada bagian Server menggunakan web server Apache, PHP Engine dan DBMS MySQL. Layanan pada server berupa web service dengan response data JSON (JavaScript Object Notation). Pada sisi Client dari Aplikasi ini,pengguna dapat mengakses EduFi melalui web browser maupun aplikasi Android. 
Computatio: Journal of Computer Science and Information Systems, volume 2, no 2, Oktober 2018

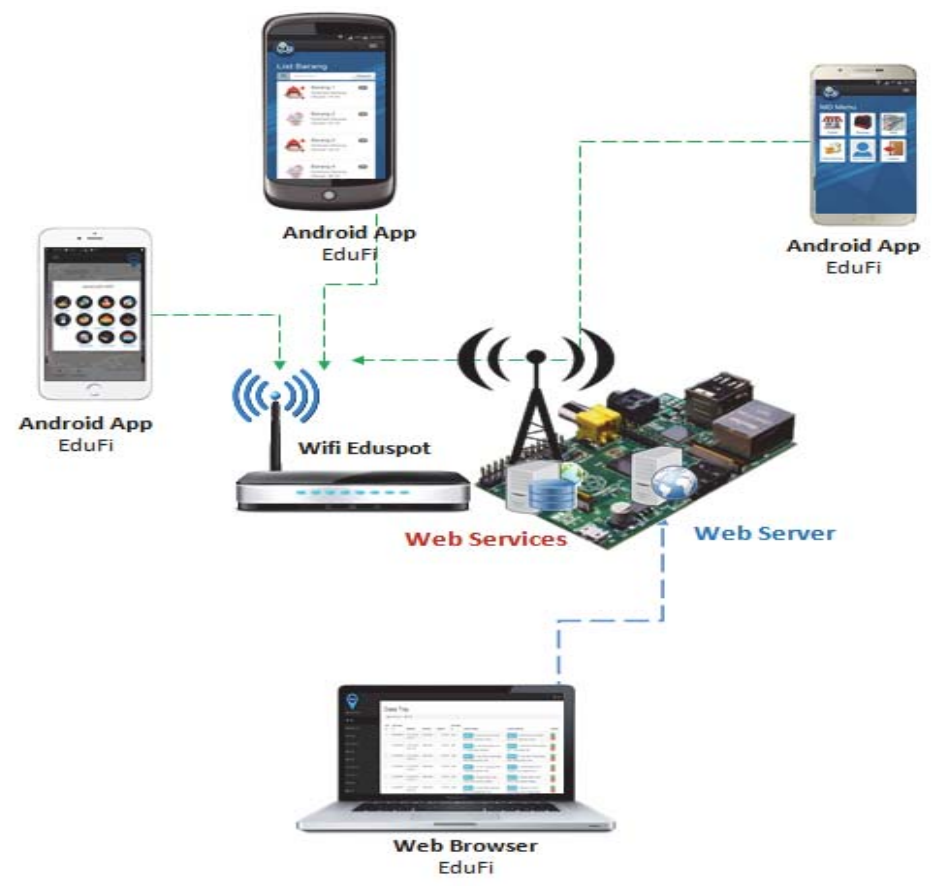

Gambar 6. Arsitektur Sistem EduFi

\section{HASIL DAN PEMBAHASAN}

Penerapan e-learning dalam proses pembelajaran sangat membantu peserta didik untuk bisa belajar sesuai dengan kecepatannya sendiri berdasarkan minat dan kebutuhan belajarnya. Materi e-learning dapat dibuat berupa file modul pdf, file presentasi powerpoint, video simulasi, forum tanya jawab, dan pemberian tugas atau quiz dalam bentuk digital, sehingga membuat proses pembelajaran lebih menarik. Untuk meningkatkan konsentrasi peserta didik, maka perlu dijamin tidak ada content negatif saat belajar dengan e-learning, dan diharakan peserta didik tetap dapat melakukan interaksi sosial di lingkungan tempat belajar. Oleh karena itu perlu di rancang penerapane-learningpada jaringan Local Area Network (LAN) tanpa terhubung dengan jaringan internet. Berdasarkan permasalahan yang dialami tersebut, maka urgensinya diperlukan sebuah aplikasi Learning Management System (LMS) yang memanfaatkan server berupa Raspberry Pi sebagai Web Server. Raspberry Pi mudah didapatkan dengan harga murah dan berukuran kecil, serhingga tidak membutuhkan ruangan khusus berpendingin AC. Dengan demikian dapat menghemat penggunaan daya listrik, dan tidak membebankan institusi dan peserta didik untuk berlangganan koneksi internet.Aplikasi LMS ini dikembangkan dengan metodologi Asynchronous JavaScript and XMLHTTP (AJAX) dan Web Services. sehingga aplikasi ini dapat diakses melalui Web Desktop maupun Aplikasi Android.

\subsection{Implementasi}

Antarmuka sistem dirancang untuk memudahkan pemakai dalam menggunakan sistem yang akan dikembangkan, sehingga lebih user friendly. Sistem EduFi didesain mempunyai dua tampilan yang berbeda bagi Dosen dan Mahasiswa. Rancangan antarmuka aplikasi ini meliputi:

Tampilan Halaman Login, Berisi informasi Aplikasi dan Form Login untuk otentikasi pengguna yang akan menggunakan sistem ini. 
Haris, et al., Pengembangan Sistem Peer-Evaluation Pada Edufi Learning Management System

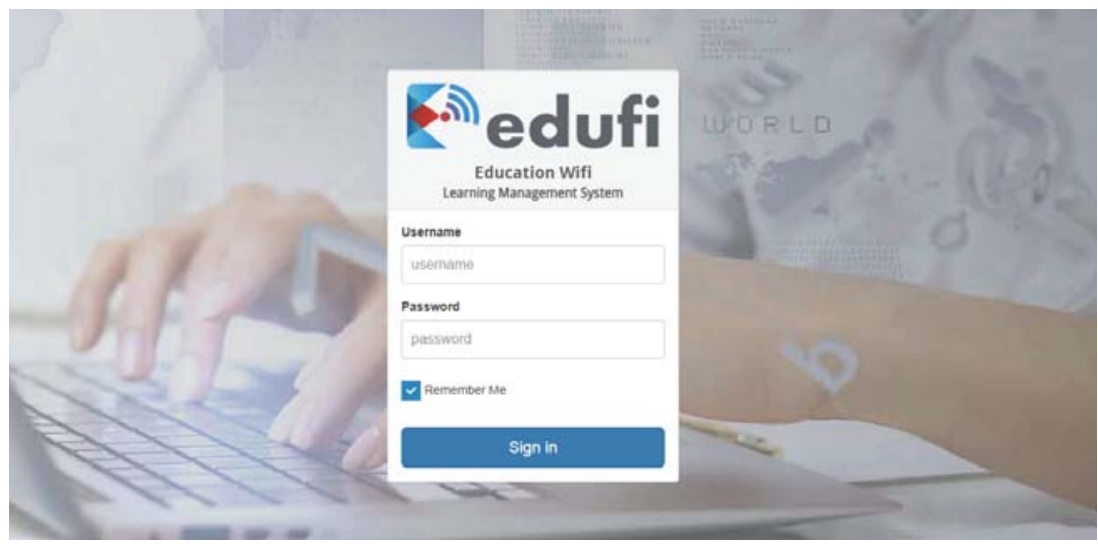

Gambar 7. Halaman Login Mahasiswa

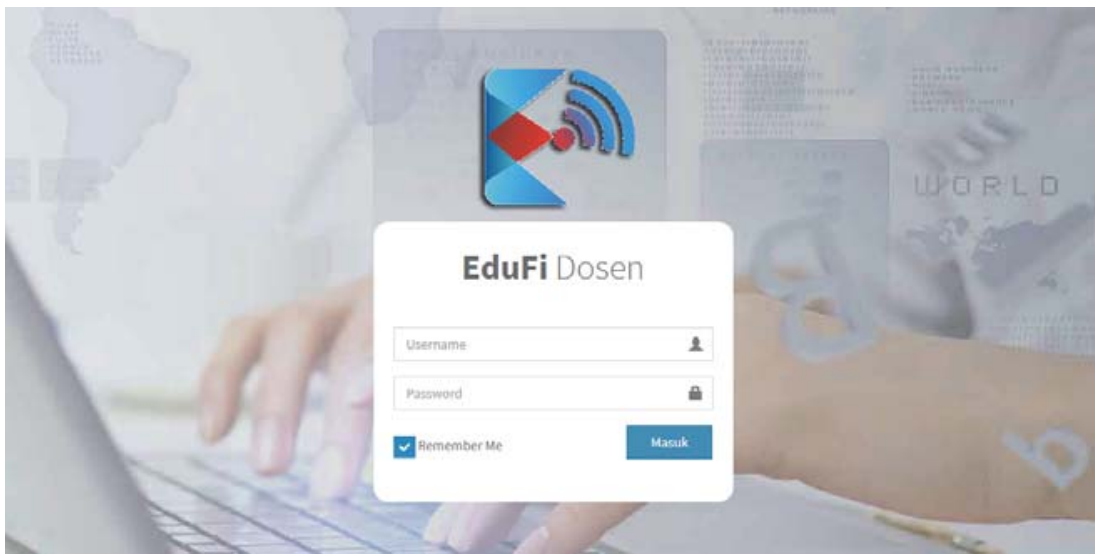

Gambar 8. Halaman Login Dosen

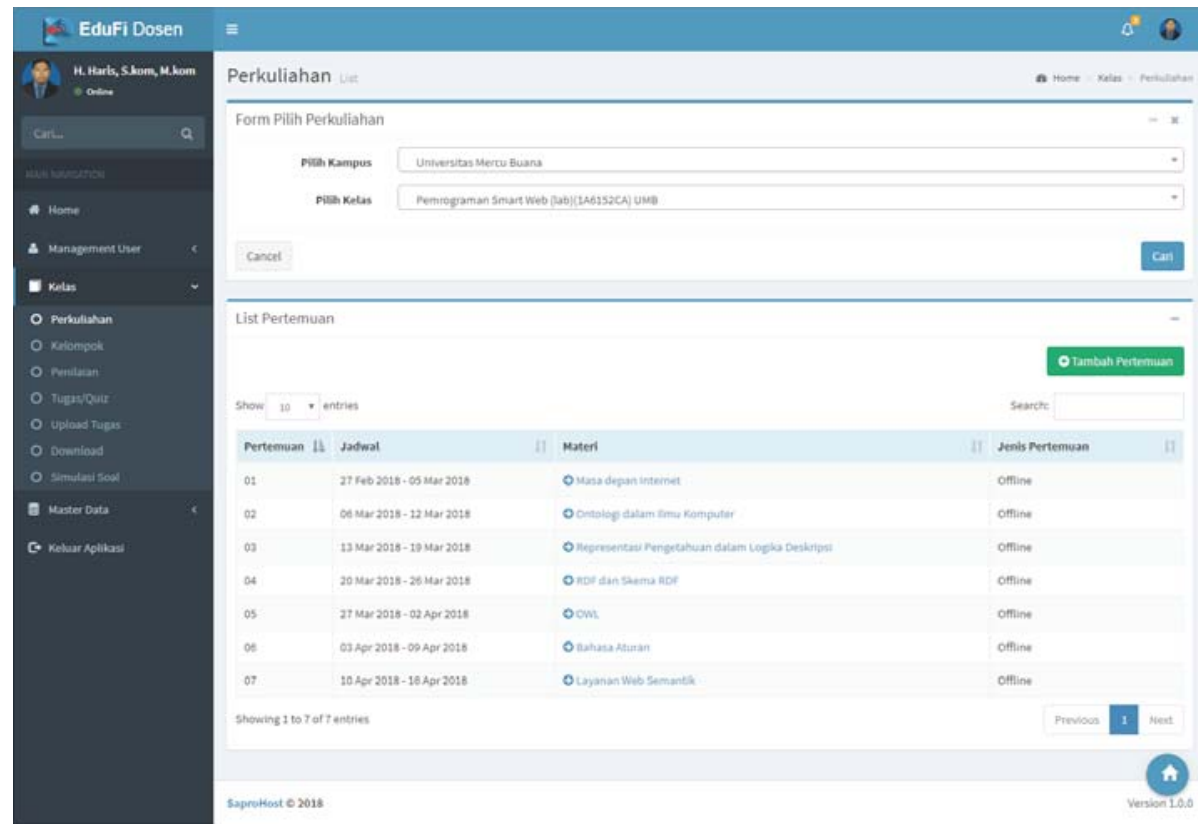

Gambar 9. Halaman Materi Perkuliahan 
Computatio: Journal of Computer Science and Information Systems, volume 2, no 2, Oktober 2018

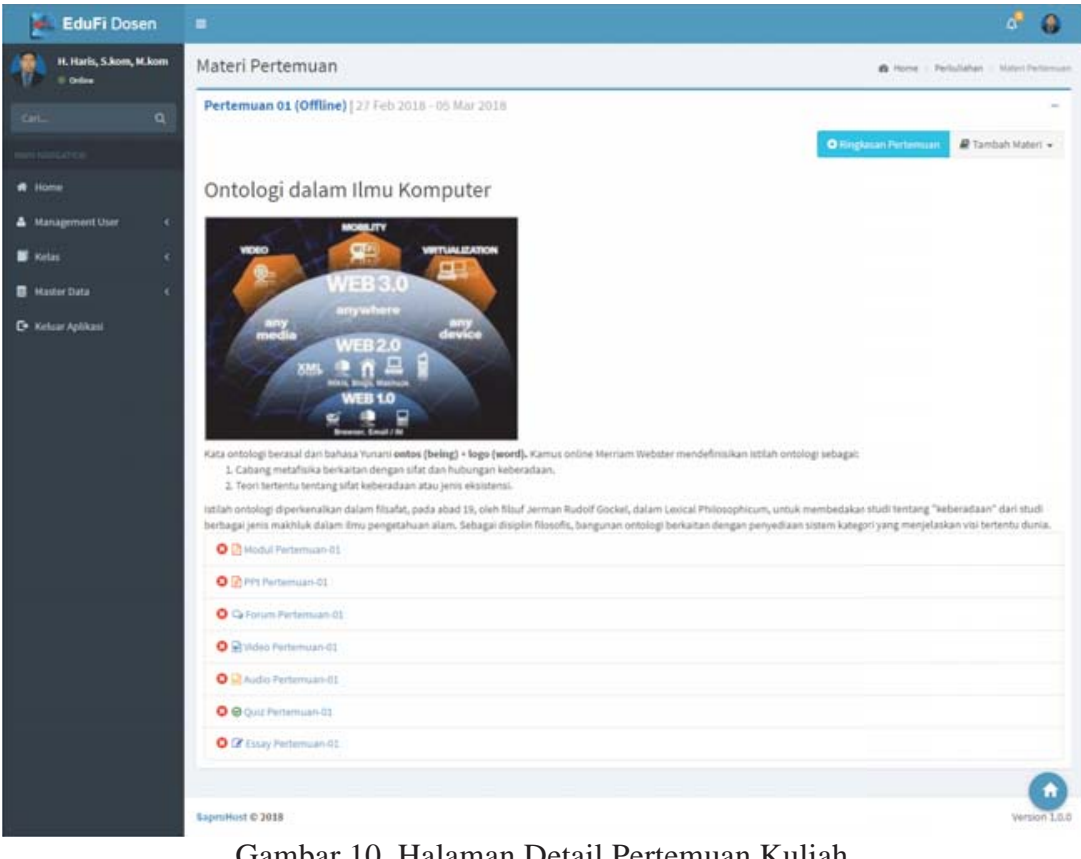

Gambar 10. Halaman Detail Pertemuan Kuliah

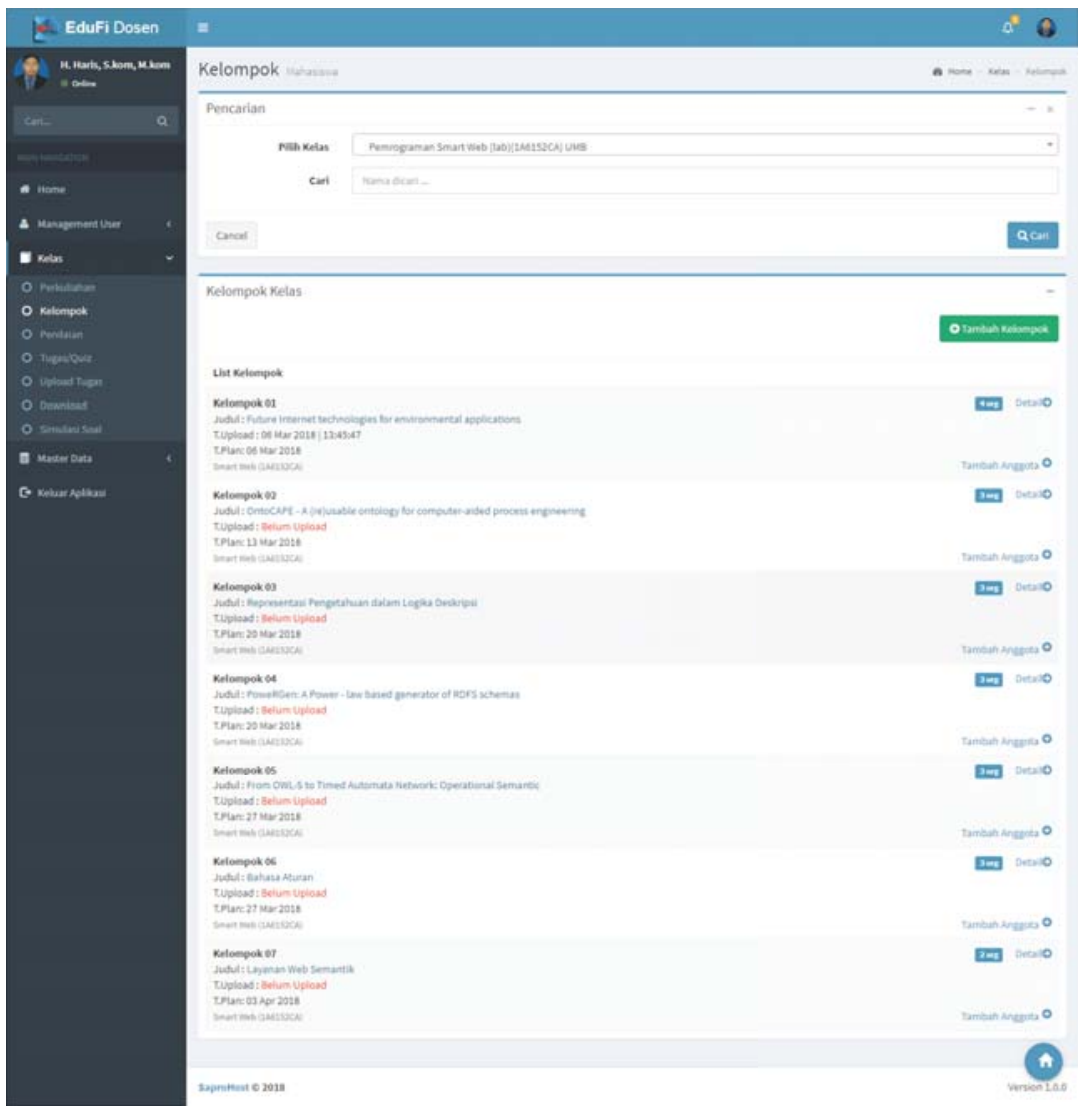

Gambar 11. Halaman Kelompok Collaborative Learning 
Haris, et al., Pengembangan Sistem Peer-Evaluation Pada Edufi Learning Management System

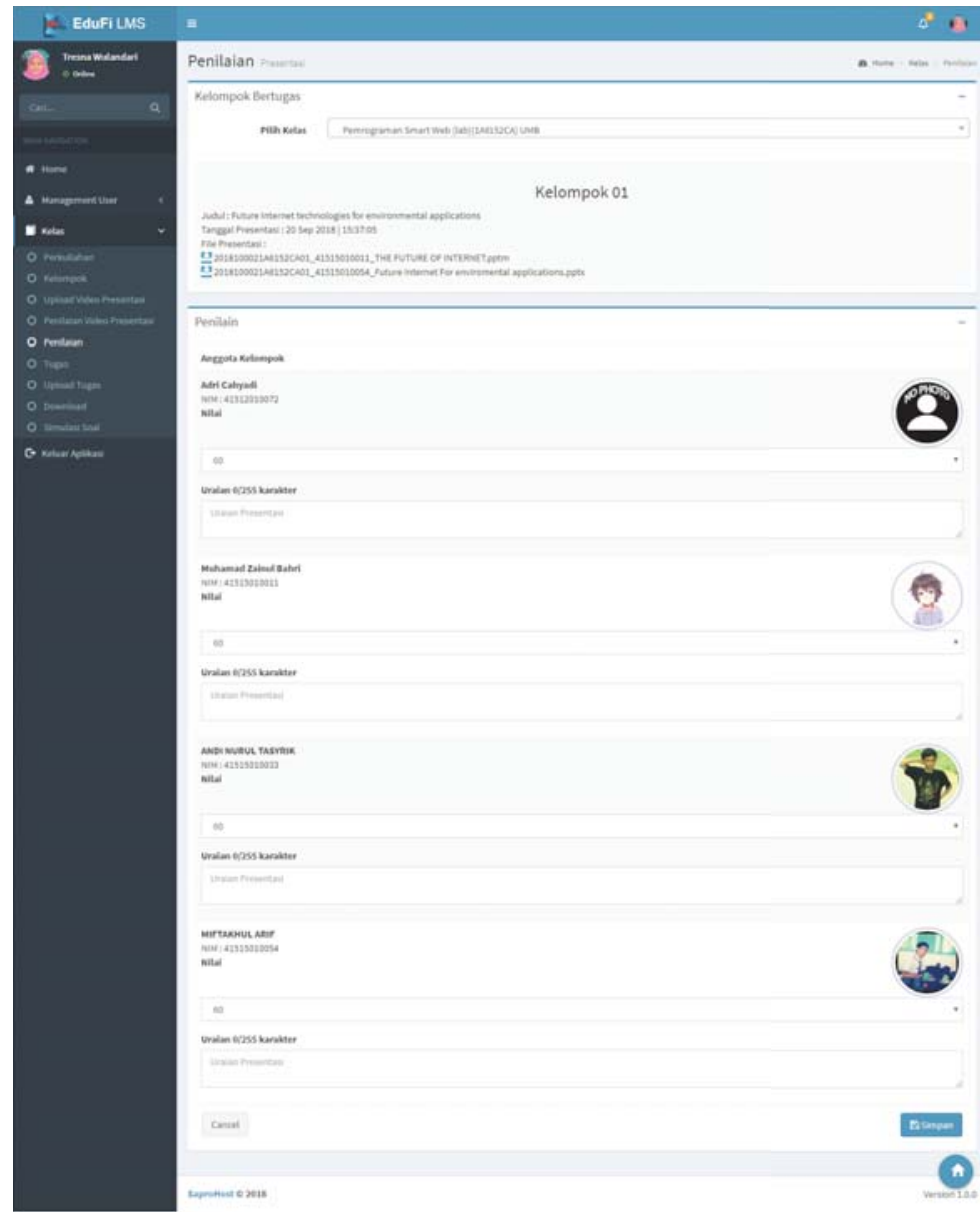

Gambar 12. Halaman Penilaian Peer-Evaluation

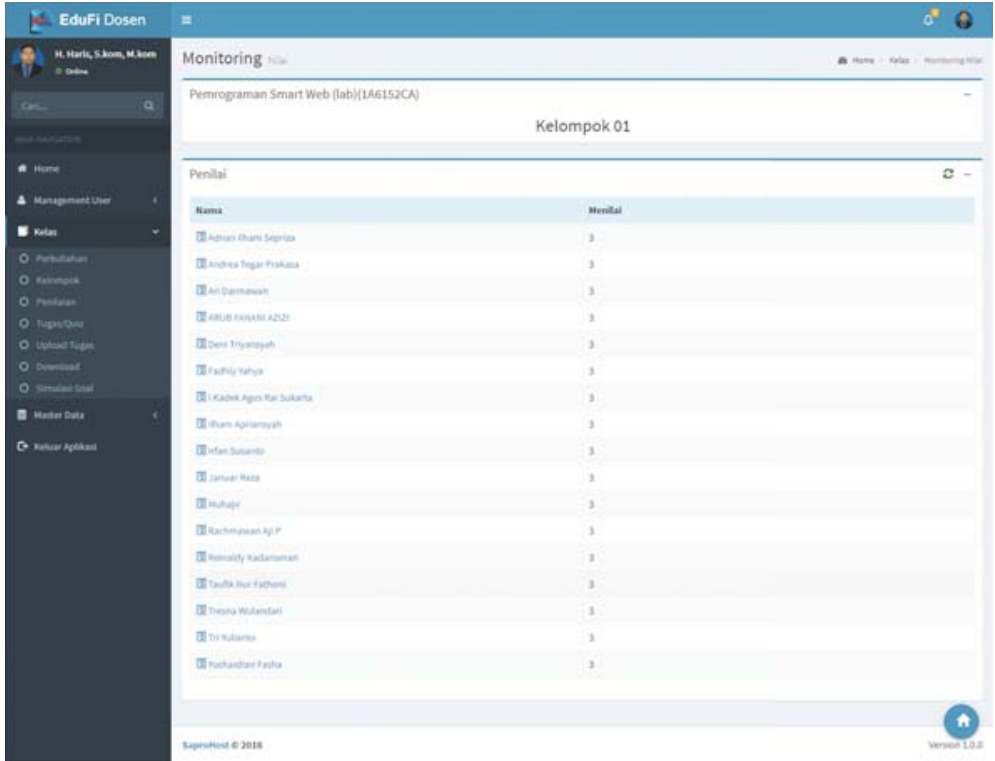

Gambar 13. Halaman Monitoring Nilai Peer-Evaluation 
Computatio: Journal of Computer Science and Information Systems, volume 2, no 2, Oktober 2018

\section{KESIMPULAN}

Berdasarkan pembahasan diatas dapat disimpulkan bahwa Sistem Learning Management System (LMS) berbasis Raspberry Pi dapat mendukung proses kegiatan belajar-mengajar dengan cepat dan mudah serta dapat meningkatkan efisiensi dan efektifitas waktu dan biaya relatif lebih terjangkau. Sistem dapat beroperasi dengan hemat daya listrik tanpa harus menggunakan ruangan pendingin, tanpa menggunakan jaringan internet. Dengan LMS pada Raspberry Pi ini pembelajaran dapat lebih interaktif dan aman dari content yang tidak baik.

Meskipun Edufi LMS dioperasikan dengan Raspberry Pi, namun dapat menerapkan PeerEvaluation dengan model pembelajaran Collaborative Learning. Dengan menerapkan PeerEvaluation, mahasiswa akan terbiasa berpikir kritis dan meringkas materi presentasi yang disampaikan oleh kelompok Collaborative Learning.

Sistem LMS ini masih bersifat sederhana dan belum begitu kompleks sehingga ada beberapa fasilitas yang dinilai masih kurang dan perlu pengembangan, antara lain:

1. Dilakukan pembagian kelas virtual dan layanan akses dalam sistem, sehingga beban server dan dosen pengajar tidak terlalu besar.

2. Sistem ini dapat dikembangkan untuk pembelajaran dengan metode pembelajaran lain yang berpusat pada Student-Centered Learning.

\section{UCAPAN TERIMA KASIH}

Penulis mengucapkan terima kasih yang sebesarnya-besarnya kepada Dr. Ir. Sunar, MS dan I. Joko Dewanto, Ir., MM. yang telah memberi masukan terhadap penelitian ini.

\section{DAFTAR PUSTAKA}

[1] Wahyuningsih Dian, dkk. E-Learning Teori dan Aplikasi. Bandung. Penerbit Informatika. 2017.

[2] Sani Mukhyar. Dampak Internet terhadap Perilaku Generasi Muda Islam. Alhadharah Jurnal Ilmu Dakwah. 2016. Vol. 15 No. 29: 1-13.

[3] Dawood Rahmad, dkk. Kelayakan Raspberry Pi sebagai Web Server:Perbandingan Kinerja Nginx, Apache, dan Lighttpd pada Platform Raspberry Pi. Jurnal Rekayasa Elektrika. 2014; Vol. 11, No. 1: 25-29.

[4] Panuntun Rizal, dkk. Perancangan Papan Informasi Digital Berbasis Web pada Raspberry Pi. Jurnal Teknologi dan Sistem Komputer. 2015; Vol.3, No.2: 192-197.

[5] Pressman, Roger, S., 2001, Software Engineering: A Practitioner's Approach,Fifth Ed. New York,McGraw-Hill Book Company.

[6] Rakhman Edi, dkk.. Raspberry Pi - Komputer Mungil yang Serba Bisa. Yogyakarta, Penerbit Andi. 2014.

[7] Dinata Andi. Physical Computing dengan Raspberry Pi. Jakarta. Penerbit Elex Media Komputindo. 2017.

[8] Ellis, K. Ryann. 2009. A Field Guide to Learning Management System. American Society For Training and Development (ASTD). 